\title{
Review Paper: Rehabilitation of Blind People and People With Low Vision in Iran
}

\author{
Marzieh Pashmdarfard ${ }^{1}$, Masoome Amini², Malek Amini ${ }^{3 *}$ \\ 1. Department of Occupational Therapy, School of Paramedical and Health, Zanjan University of Medical Sciences, Zanjan, Iran \\ 2. Department of Clinical Psychology, School of Psychology, Tehran Branch, Payame Noor University, Tehran, Iran. \\ 3. Department of Occupational Therapy, School of Rehabilitation Sciences, Iran University of Medical Sciences, Tehran, Iran.
}

Citation: Pashmdarfard M, Amini M, Amini M. Rehabilitation of Blind People and People With Low Vision in Iran. Iranian Rehabilitation Journal. 2016; 14(2):77-84. https://doi.org/10.18869/nrip.irj.14.2.77

: https://doi.org/10.18869/nrip.irj.14.2.77

\section{Article info:}

Received: 21 Dec. 2015

Accepted: 13 Apr. 2016

\section{Keywords:}

Blindness, Low vision, Occupational therapy, Rehabilitation

\section{A B S T RACT}

Objectives: The blind and visually disabled people form a predominant group in the disabled society and hence, need greater attention. Most of the rehabilitation therapists, especially occupational therapists, do not focus on this group. Thus, the aim of the study is to shed light on the issue of negligent attitude of rehabilitation therapists, especially occupational therapists, toward blind and visually-impaired people.

Methods:To perform this study, a systematic, evidence-based process (Duffy 2005) was used. Data for the study was gathered from the following sources: Electronic databases: Medline PubMed, CINAHL, OVID Medline, CINAHL Plus with Full Text, Cochrane Databases of Systematic Reviews, ProQuest, UpToDate, Web of Science, OT Search, OTDirect, PEDro, SID, Magiran, IRAN MEDEX, MEDLIB, and IRANDOC.

Results: From accessible databases, 112 articles related to blind and people with low vision in Iran were found; of these, only 17 articles have been included in this study.

Discussion: Proper assessment of the visually disabled is required to implement the appropriate intervention technique. Occupational therapists need to pay special attention to the visually disabled people.

\section{Introduction}

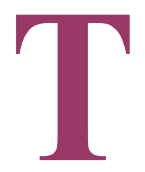

here are a significant number of people with vision disabilities like blindness and low vision. In 1983, Barbara defined a visually disabled child as a child whose learning process is hindered due to a visual disability. Special teaching methodologies and materials need to be created to make the learning environment conducive to them so that they can attain optimal academic achievement (which is obtained through vision). Legally blind: Legally blind person is a person with visual acuity of 20/200 or less (according to the Snellen eye test) in the dominant eye after correction. Such people have a restricted field of vision, and the widest diameter of the visual field in the dominant eye subtends an angle not more than 20 degrees [1].

Channel vision refers to the severe limitation of the visual fields of a person that affects his/her ability to read, drive, and exercise [1]. Low-vision is a condition in which the vi-

\section{* Corresponding Author:}

Malek Amini, PhD

Address: Department of Occupational Therapy, School of Rehabilitation Sciences, Iran University of Medical Sciences, Tehran, Iran.

Tel: +98 (912) 5424533

E-mail:malekamini8@gmail.com 
sual acuity in the dominant eye after maximum recovery is 20/70 or less [1]. Educational blind children are those who lack the visual ability to read and write and rely on other senses such as hearing and touch [1]. Functional vision refers to the way by which a person uses his/her vision [1].

In developing countries, blindness and visually impairments are considered as two important issues in the development of health, economic, and social sectors [2]. According to the World Health Organization, nearly 38 million people worldwide are blind and around 110 million people suffer from visual problems. In addition, this number is increasing day by day [2]. More than $90 \%$ of visually-disabled people live in developing countries $[3,4]$. The prevalence of blindness in Asian developing countries is around $3.0 \%$ to $4.4 \%[5,6]$. In Iran, there are about 160 thousand blind people and 700 to 900 thousand people with low vision [7]. Amirkhani, et al. collected data from 34 universities of medical sciences in Iran and found that the prevalence of problems related to vision among children in the age group of 6-4 years, first and third base elementary, first middle and first high school are $4.7 \%, 3.8 \%, 5.8 \%$, and $4.1 \%$, respectively [8].

Kermanshah University of Medical Sciences reported the highest number of visual impairment cases (10.59\%). Other institutes reporting the maximum number of cases are Iran University of Medical Sciences (6.86\%), Tehran University of Medical Sciences (6.60\%) (Tehran province), and Kerman (6.81\%) [8]. Most of the studies indicated that visual impairment affects the person's quality of life, decreases his/her independency, and also limits their social participation $[9,10]$. Nowadays, assessment and promotion of quality of life of people with disabilities are the goals of rehabilitation programs [11].

The main purpose of rehabilitation services, especially occupational therapy, is to improve the quality of life and encourage participation of people with disabilities [12]. Although there are many visually-impaired and

Table 1. Key words. blind people in our country, such people do not employ the services of rehabilitation and occupational therapists due to social and cultural taboos. Thus, the aim of this review is to evaluate the studies on the visually impaired people in Iran and shed light on the issue of negligent attitude of rehabilitation therapists, especially occupational therapists, toward blind and visually-impaired people.

\section{Methods}

To perform this study, a systematic, evidence-based process (Duffy 2005) was used [13]. Data for the study was gathered from the following sources:

- Electronic databases: Medline PubMed, CINAHL, OVID Medline, CINAHL Plus with Full Text, Cochrane Databases of Systematic Reviews, ProQuest, UpToDate, Web of Science, OT Search, OTDirect, PEDro, SID, Magiran, IRAN MEDEX, MEDLIB, and IRANDOC.

- Google Scholar

- Famous Iranian and Foreign journals in the field of low vision and blindness: Iranian Journal of Pediatrics (IJP), Iranian Rehabilitation Journal (IRJ), Archives of Physical Medicine and Rehabilitation, Developmental Medicine \& Child Neurology, Physical and Occupational Therapy in Pediatrics, American Journal of Occupational Therapy, and many more. Key words that were used in accordance with MESH have been mentioned in Table 1. The inclusion and exclusion criteria for incorporation of materials in the study are categorized in Table 2.

\section{Result}

On searching accessible databases, a total of 112 articles on the blind and people with low vision in Iran were found. Based on the inclusion and exclusion criteria, 92 articles were removed. Three more articles were

Low vision, Participation, Iranian children with low vision, Visual impairments, Environmental barriers, Environmental adaptation, Adaptation, School children, Disability, Blindness

Table 2. Inclusion and exclusion criteria.

Пranian Rehabilitation Journal

\section{Exclusion Criteria}

Articles written in a language other than Persian and English; Articles other than on the subject of diagnosis of blindness, low vision, and visual impairments;

Articles related to the blind population of countries other than Iran.
Inclusion Criteria

Articles about studies conducted on visually disabled and impaired Iranians;

Articles whose abstracts or full texts are accessible; Articles published from 2000 to 2016. 


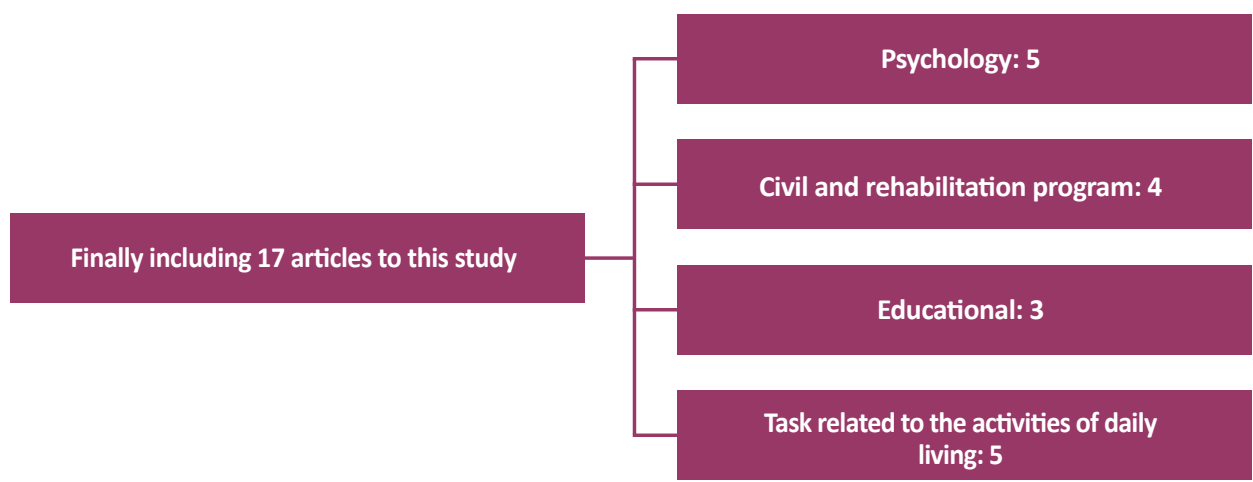

Figure 1. Results of systematic search about proceeding for Iranian blinds and low visions.

Iranian Rehabilitation Journal

removed due to their plagiarized content. Therefore, the study result is based on the remaining 17 articles. Articles related to the area of participation are categorized in Figure 1. It is important to mention that some articles cover more than one subject area. Therefore, these articles are categorized in more than one area. The findings are presented in Table 3.

\section{Discussion}

On reviewing the included studies, it was found that these studies mostly concentrate on four areas: psychology [17, $19,20]$, rehabilitation and civil program $[14,16,20,21]$, education [19, 21, 22, 23, 24, 25, 26, 27], and daily living activities $[14,17,22]$. The most important thing is that re-

Table 3. Results of analysis of the included articles.

\begin{tabular}{|c|c|c|c|c|c|}
\hline $\begin{array}{l}\text { पूँ } \\
\frac{0}{4} \\
\frac{0}{4}\end{array}$ & Authors & Year & Title & Method & Results \\
\hline \multirow{3}{*}{ 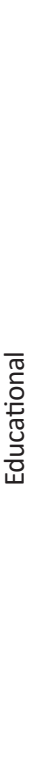 } & $\begin{array}{l}\text { Hoseinkhani } \\
\text { et al. [14] }\end{array}$ & 2015 & $\begin{array}{l}\text { Using Virtual Reality Technology } \\
\text { and a haptic robot for teaching } \\
\text { blind students }\end{array}$ & $\mathrm{RCT}$ & $\begin{array}{l}\text { Virtual environment is a useful educa- } \\
\text { tional tool for blind students with respect } \\
\text { to cost and time aspects. }\end{array}$ \\
\hline & $\begin{array}{c}\text { Kakojoibari } \\
\text { et al. [15] }\end{array}$ & 2014 & $\begin{array}{l}\text { Comparison of reading literacy } \\
\text { than students with visual impair- } \\
\text { ment and normal students }\end{array}$ & $\begin{array}{l}\text { Causal-compar- } \\
\text { ative study and } \\
\text { performed by } \\
\text { the use of PIRLS } \\
\text { (2006) Interna- } \\
\text { tional standard- } \\
\text { ized booklet as } \\
\text { an instrument }\end{array}$ & $\begin{array}{l}\text { Regarding the levels of reading literacy } \\
(P=0.017) \text { and understanding of literal } \\
\text { contents, there was a significant differ- } \\
\text { ence between students with visual im- } \\
\text { pairment and normal students ( } P=0.07) \text {. }\end{array}$ \\
\hline & $\begin{array}{c}\text { Mahjoob et } \\
\text { al. [16] }\end{array}$ & 2010 & $\begin{array}{l}\text { The effect of color filters on the } \\
\text { visual acuity and contrast sensi- } \\
\text { tivity in low vision patients }\end{array}$ & $\begin{array}{l}\text { Case-control } \\
\text { study with ran- } \\
\text { dom sampling } \\
\text { method }\end{array}$ & $\begin{array}{l}\text { Contrast sensitivity evaluates the visual } \\
\text { performance better than visual acuity in } \\
\text { low vision. It showed that colored filter } \\
\text { overlays are unlikely to provide a clinically } \\
\text { significant improvement in the visual } \\
\text { function of low vision patients. }\end{array}$ \\
\hline
\end{tabular}




\begin{tabular}{|c|c|c|c|c|c|}
\hline$\frac{\bar{d}}{\frac{0}{4}}$ & Authors & Year & Title & Method & Results \\
\hline
\end{tabular}

A comparison of self- esteem

Esfanjani et $2013 \quad$ letes and non-athletes from 13

al. [17]

Sarabandi et

al. [18]

2013 to 30 years in

Mashhad

The relationship between impaired visual function and quality of life of the blind

The effectiveness of cognitive-

behavioral group therapy on

Yaghotian et

al. [19]

self- concept of visually impaired adolescents

The influence of the olfaction, audition and tactile senses in

Namaei

Kohal et al.

[20]

mobility and orientation of blinds

Effectiveness of life skills edu-

Pourseyyed

2010

cational program on blind and

et al. [21]

low-vision university students compatibility

Sarabandi et

al. [22]

2014 The effect of rehabilitation Ser-
vices on quality of life for the
blind

The rate of satisfaction of low vision aids and quality of life in

Feridooni et

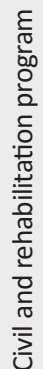

al. [23]

low visions referring to the red-

crescent's low vision center of

Tehran since 21 June 2011 till 21 June 2012

Bemanian et

al. [24]

Effective aspects on designing appropriate urban park for the blind

Analysis method

Blinds perception of architecture and criteria and designing patterns for theme study
Contextual study

Exercise has a significant role in the promotion of self-esteem and mental health in blind athletes.

Defects of peripheral vision, stereopsis

Descriptive-analytical study

Semi-experimental design with random assign ment of (ran-

domly assigning)

participants in

experimental

and control

groups, with

pre-test and

post-test

RCT

The blind study group gave the highest rating to audition sense, followed by the senses of olfaction and tactile.

RCT

Descriptive ana-

lytical study

Cross-sectional

The quality of life has been increased in different aspects after the use of low vision aids.

Avoiding simple and monotonous designing, lack of using smooth and slippery materials on the floor to stimulate the sense of touch in the blind, using shady trees and scented plants to stimulate the sense of smell in the blind, creating exciting spaces near the entrances to stimulate hearing are effective in increasing the presence of the blind people in urban parks.

Quest for recognition of blinds understanding of architecture and present a pattern of a suitable place with their understandings and generally a design for an entertainment and Qualitative cultural complex for a rest and passing a nice research and remembering time for everyone with putting some preferences in the area for Blind people and making some facilities and enjoying conditions for them with have an eye on basis of a landscape architecture project. 


\begin{tabular}{|c|c|c|c|c|c|}
\hline $\begin{array}{l}\frac{\mathrm{d}}{\mathrm{J}} \\
\frac{\mathrm{q}}{4}\end{array}$ & Authors & Year & Title & Method & Results \\
\hline \multirow{5}{*}{ 定 } & $\begin{array}{l}\text { Mahjoob et } \\
\text { al. [16] }\end{array}$ & 2010 & $\begin{array}{l}\text { The effect of color filters on the } \\
\text { visual acuity and contrast sensi- } \\
\text { tivity in low vision patients }\end{array}$ & $\begin{array}{l}\text { Case-control } \\
\text { study with ran- } \\
\text { dom sampling } \\
\text { method }\end{array}$ & $\begin{array}{l}\text { Contrast sensitivity evaluates the visual per- } \\
\text { formance better than visual acuity in low } \\
\text { vision. Contrast sensitivity showed that Col- } \\
\text { ored filter overlays are unlikely to provide } \\
\text { a clinically significant improvement in the } \\
\text { visual function of low vision patients. }\end{array}$ \\
\hline & $\begin{array}{l}\text { Pourseyyed } \\
\text { et al. [21] }\end{array}$ & 2010 & $\begin{array}{l}\text { Effectiveness of life skills educa- } \\
\text { tional program on the compat- } \\
\text { ibility of blind and low-vision } \\
\text { university students }\end{array}$ & RCT & $\begin{array}{l}\text { The life skills' educational program is an } \\
\text { effective way to increase the compatibil- } \\
\text { ity of blind and low-vision students. }\end{array}$ \\
\hline & $\begin{array}{l}\text { Feridooni et } \\
\text { al. [23] }\end{array}$ & 2012 & $\begin{array}{l}\text { The rate of satisfaction of low } \\
\text { vision aids and quality of life in } \\
\text { low visions referring to the red- } \\
\text { crescent's low vision center of } \\
\text { Tehran since } 21 \text { June } 2011 \text { till } 21 \\
\text { June } 2012\end{array}$ & $\begin{array}{l}\text { Cross-sectional } \\
\text { study }\end{array}$ & $\begin{array}{l}\text { The quality of life has been increased } \\
\text { in different aspects after the use of low } \\
\text { vision aids. }\end{array}$ \\
\hline & $\begin{array}{l}\text { Aali et al. } \\
\qquad[26]\end{array}$ & 2014 & $\begin{array}{l}\text { Comparison of physical fitness in } \\
\text { blind, deaf and normal children }\end{array}$ & $\begin{array}{l}\text { Case-control } \\
\text { study }\end{array}$ & $\begin{array}{l}\text { Early screening of physical fitness and } \\
\text { designing proper physical fitness and } \\
\text { exercise training programs appears to be } \\
\text { essential in improving the physical condi- } \\
\text { tion of the blind children. }\end{array}$ \\
\hline & $\begin{array}{l}\text { Askari et al. } \\
\quad[27]\end{array}$ & 2010 & $\begin{array}{l}\text { Environment and blindness situ- } \\
\text { ation in Iran }\end{array}$ & $\begin{array}{l}\text { A qualitative } \\
\text { phenomenologi- } \\
\text { cal method }\end{array}$ & $\begin{array}{c}\text { Occupational therapists and other health } \\
\text { care professionals who are involved with } \\
\text { blind people to become more competent } \\
\text { during assessment, counseling, teaching, } \\
\text { giving support, or other interventions as } \\
\text { needed to assist blind people. }\end{array}$ \\
\hline
\end{tabular}

Ilranian Rehabilitation Journal

habilitation therapists, especially occupational therapists, indicate that their main goal is to create a disable-friendly environment, but they have not yet reported any impressive intervention for blind and visually-impaired people. Askari, et al. have suggested that the visually-impaired and disabled people should be asked to perform a series of modifications to the environmental accommodations and in the design of the surrounding environment to make it friendly for the blind and low vision people [30-32].

Before any interventions, it is essential to carry out a comprehensive assessment of the requirements of the blind and people with low vision. The lives of these groups of people should be assessed using culture-based questionnaires and scales. The Children Participation Questionnaire (CPQ) and Children Participation Assessment Scale-Child \& Parent version (CPAS-C \& CPAS-P) are considered to be suitable for 4-6 years old and 6-12 years old children, respectively $[12,28]$. These questionnaires are based on Occupational Therapy Practice Framework (OTPF) [29] and cover all areas of life and occupation (ADL, IADL, leisure, education, rest/ sleep, play, work, and social participation). These assessments can help in assessing the needs, demands, and limitations of the blind participants, resulting in the designing of comprehensive intervention programs for them.

\section{Conclusion}

Due to the growing number of visual impairment cases worldwide, it has become a necessity to design good and appropriate interventions for them. Occupational therapists have a comprehensive role among the rehabilitation members. Based on their philosophy of 'enabling the disabled,' it is necessary to focus on the blind and visuallyimpaired people and do extensive and comprehensive studies for the advancement of this group of people.

\section{Acknowledgments}

The current research hasn't received any financial support

\section{Conflict of Interest}

The authors declared no conflict of interests. 


\section{References}

[1] Nameni M, Hayat Roshanaee A, Torabi F. [Psycho-revolution, training and rehabilitation of blindness (Persian)]. Tehran: Ministry of Culture and Islamic Guidance; 2010.

[2] Ramezani A, Pardis M, Rafati N, Kazemi-Moghaddam M, Katibeh M, Rabbanikhah ZR. Causes of visual impairment among patients referred to a visual rehabilitation clinic in Iran. Korean Journal of Ophthalmology 2012; 26(2):80-83. doi: 10.3341/kjo.2012.26.2.80

[3] Tabbara KF, El-Sheikh HF, Shawaf SS. Pattern of childhood blindness at a referral center in Saudi Arabia. Annals of Saudi Medicine. 2005; 25(1):18-21. PMID: 15822489

[4] Hu S. Blindness as a challenging medical and social problem in China. Yan ke xue Bao. 2002; 18(1):4-8. PMID: 15510666

[5] Baasanhu J, Johnson G, Burendei G. Prevalence and causes of blindness and visual impairment in Mongolia: A survey of populations aged 40 years and older. Bulletin of the World Health Organization. 1994; 72(5):771-76. PMID: 7955027

[6] Dandona L, Dandona R, Srinivas M, Giridhar P, Vilas K, Prasad MN, et al. Blindness in the Indian state of Andhra Pradesh. Investigative ophthalmology \& visual science. 2001; 42(5):908-16. PMID: 11274066

[7] Khosravi S, Khosravi F. [A study on the status of the special library for the blind and visually impaired of the National Library of Iran and proposing solutions for improving it (Persian)]. National Studies on Librarianship \& Information Organization. 2010; 21(1):63-76.

[8] Amirkhani M, Ziaedini S, Dashti M, Aminaei T, Ardalan G, Mirmoghtadaee $P$, et al. [Prevalence of visual impairments among school-aged children: The results of a national screening program (Persian)]. Journal of Isfahan Medical School 2010; 27(101):717-23.

[9] Klein B, Klein R, Lee K, Cruickshanks K. Performancebased and self-assessed measures of visual function as related to history of falls, hip fractures and measured gait time. Ophthalmology. 1998; 105(1):160-64. doi: 10.1016/s01616420(98)91911-x

[10] West S, Munoz B, Rubin G, Bandeen-Roche K, Zeger S, Fried L. Function and visual impairment in a population based study of older adults. Investigative Ophthalmology \& Visual Science. 1997; 38(1):72-82. PMID: 9008632

[11] Breslow L, Bullinger M. Evaluating quality-of-life measures for clinical trials in Germany. 1991; 12(4):91-105. PMID: 1663863

[12] Amini M, Hassani Mehraban A, Haghni H, Asgharnezhad A, Khayatzade Mahani M. Development and validation of Iranian children's participation assessment scale. Medical Journal of the Islamic Republic of Iran. 2016; 30(1):333.

[13] Law M, Dermid JM. Evidence-based rehabilitation: A guide to practice. New York: Slack Inc.; 2008.

[14] Hoseinkhani S, Arbabtafti M, Payeganeh G. [Using virtual reality technology and a haptic robot for teaching blind students (Persian)]. Journal of Technology \& Education. 2015 9(4):265-72

[15] Kakojoibari A, Shobeiri S, Shoaie H, Mohtashami T. [Comparison of Reading Literacy than Students with Visual Im- pairment and Normal Students (Persian)]. Journal of Rehabilitation. 2014; 14(4):58-65.

[16] Mahjoob M, Heravian J, Validad M, Moghadam HM, Hoseini T, Tavakoli R. [The effect of color filters on the visual acuity and contrast sensitivity in low vision patient (Persian)]. Journal of Babol University of Medical Sciences. 2010; 11(6):53-7.

[17] Esfanjani RM, Javanmard MG, Arazi H, Yeganegi S. [A Comparison of Self- esteem and Mental Health in Blind Athletes and Non-athletes from 13 to 30 years in Mashhad (Persian)]. Journal of Exceptional Children. 2013; 13(2):71-9

[18] Sarabandi A, Kamali M, Mobaraki H. [The relationship between impaired visual function and quality of life of the blind (Persian)]. Journal of Rehabilitation Sciences and Research. 2013; 8(6):1015-023.

[19] Yaghotian M, Soliemanian A, Darrodi H. The effectiveness of cognitive-behavioral group therapy on self- concept of visually impaired adolescents. Iranian Rehabilitation Journal 2015; 13(4):6-12.

[20] Kohal AN, Tafreshi ST, Aghasi M. The influence of the olfaction, audition and tactile senses in mobility and orientation of blinds. Iranian Rehabilitation Journal. 2015; 1(4):13-19.

[21] Pourseyyed S, Habibollahi S, Faramarzi A. [Effectiveness of life skills educational program on blind and low-vision university students compatibility (Persian)]. Iranian Journal of Educational Strategies. 2010; 3(1):7-11.

[22] Sarabandi A, Mobaraki H, Chabok K, Soltani S. [The effect of rehabilitation Services on quality of life for the blind (Persian)]. Modern Rehabilitation Journal. 2014; 7(4):48-56.

[23] Feridooni F, Broumand MG, Tabatabaeei SM. [The rate of satisfaction of low vision aids and quality of life in low visions referring to the red-crescent's low vision center of Tehran since 21 June (Persian)]. Journal of Rehabilitation Medicine. 2013; 2(1):15-22.

[24] Bemanian M, Khamaneh MD, Ahmadi F. [Effective aspects on designing appropriate urban park for the blind (Persian)] Journal of Urban Landscape Research. 2015; 1(2):29-39.

[25] Farzin AA, Sheibani A. [Blinds perception of architecture and criteria and designing patterns for theme (Persian)] Baghe Nazar Journal. 2008; 7(13):61-72.

[26] Aali S, Rezazade F. [Comparison of physical fitness in blind, deaf and normal children (Persian)]. Studies in Sport Medicine. 2014; 5(14):135-50.

[27] Askari S, Shafaroudi N, Kamali M, Khalafbeigy M. Environment and Blindness situation in Iran. Iranian Rehabilitation Journal. 2010; 8(11):34-42.

[28] Amini M, Hassani Mehraban A, Rostamzade O. [Translation, cultural adaptation, face, content and convergent validity of children participation questionaire into Persian (Persian)]. Journal of Rehabilitation Medicine. 2016; 5(2):151-57.

[29] American Occupational Therapy Association. Occupational therapy practice framework: Domain and process. $3^{\text {rd }}$ ed. American Journal of Occupational Therapy. 2014; 48(1):3-48.

[30] Kouhsali MS, Mirzamani SM, Mohammadkhani P, Karimlou M. Comparison of social adjustment between mothers of 
educable mentally retarded girls and mothers of normal girls in Kashan. Journal of Rehabilitation. 2007; 15(8):40-7.

[31] Azad A, Ebrahimi E. Compression study of two point discrimination test between normal and blind people's hand in decade 10-20. Journal of Rehabilitation. 2001; 1(3):38-42.

[32] Ostadi-Moghaddam H, Khabbaz-Khoub M, Yekta A, Heravian J, Mehdi-Zadeh AR. An investigation in causes of severe visual impairment and blindness of the students from the blind schools of mashhad. Journal of Rehabilitation. 2007; 8(1). 
